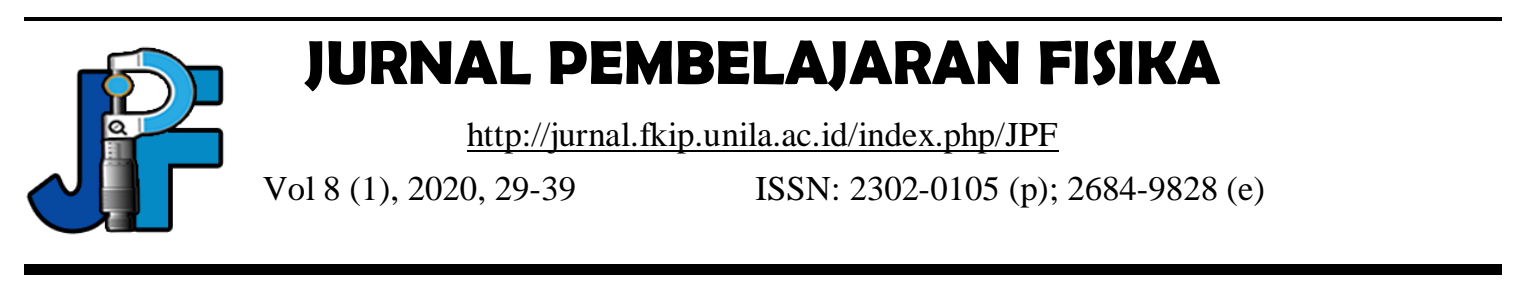

\title{
The Effect of Sense of Community and Self-Efficacy on Students' Higher-Order Thinking Skills In WhatsApp-assisted Physics Learning
}

\author{
Ratna Widyaning Tyas*, Nengah Maharta, Wayan Suana \\ Department of Physics Education, University of Lampung, Indonesia \\ *e-mail: Ratnawidyaningtyas14@gmail.com
}

\begin{abstract}
This study aimed to determine the effect of sense of community (SC) on higher order thinking skills (HOTS), self-efficacy (SE) on higher order thinking skills (HOTS), and SC and SE on HOTS of students in learning Newton's Law of motion assisted with WhatsApp application. The sample in this research were students of class X MIPA 5 and class XI MIPA 6 with 68 students in total at SMAN 13 Bandar Lampung in the academic year 2019/2020. The research design applied in this study was a one-shot case study. Data analysis techniques using product moment correlation, simple linear regression and multiple linear regression. The results showed that there is no effect between SC on HOTS, SE on HOTS, and the effect of the combination of SC and SE on HOTS. With a correlation value 0.095, the coefficient of determination R square of 0.009 and sig $0.441>0.05$, SE on HOTS with a correlation value of 0.052 , the determination coefficient of $\mathrm{R}$ square of 0.003 and sig of $0.674>0.05$, and combination of SC and SE on HOTS with a correlation value of 0.114 , the coefficient of determination $\mathrm{R}$ square of 0.013 and sig $0.653>0.05$. Based on the findings, it can be concluded that there is no effect of SC on HOTS, SE on HOTS, and effect of the combination of SC and SE on HOTS in learning physics assisted with WhatsApp application.
\end{abstract}

Keywords: Higher Order Thinking Skills (HOTS), Self-Efficacy (SE), Sense of Community (SC), Whatsapp Application.

DOI: http://dx.doi.org/10.23960/jpf.v8.n1.202004 


\section{INTRODUCTION}

Nowadays, the development of science and technology is very rapid where in the 21 st century raises new demands in all aspects of life, so that adequate quality resources are needed. What is meant is quality education. Quality of education can encourage to form ideas, arouse thoughts, share feelings, and change lives as individuals (Budiarti, et al. 2019). Improving the quality of education must be produced through the implementation of a quality education system. To meet the demands of learning in the 4.0 revolution era there is a need for special skills that must be possessed by students, one of which is Higher Order Thinking Skills (HOTS). However, based on the results of research conducted by Marliani, Setiawati \& Walid (2019) it is known that the UN, USBN, and UAS questions in the field are still relatively low to measure students' HOTS. Moreover, based on the results of research conducted by a survey institute that routinely evaluates the achievement of results learning of students in Science and Mathematics namely PISA in 2016 states that Indonesia's position is ranked 62 out of 70 countries. This achievement in Indonesia indicates that there are still problems in the Indonesian education system. Based on the results of the PISA survey also explained that the weakness of students in Indonesia is their inability when faced with problems that basically contain facts, principles, theories, and laws that have strong evidence obtained from a series of scientific activities (Marsyakha, Suyatna \& Herlina, 2020), so requires critical thinking skills, creative and high level thinking skills.

The existence of HOTS of good students will certainly improve learning outcomes, for that the teaching and learning process must be done consciously and well organized, which in these activities of course students must have confidence in their abilities (self-efficacy) such as which was stated by Bandura and Wood in Ahriana, Yani and Maruf (2016: 21) that Self-efficacy is a belief in one's ability to move motivation, cognitive resources, and a series of actions needed to meet the demands of the situation at hand. The existence of high self-efficacy, then students will be more confident to obtain better learning results, because if students have a high SE in they will be able to motivate in learning program. Through self-regulation in setting goals or targets, self-observation, and self-evaluation, and setting strategies for using a learning time to achieve the goals that are targeted, so students who have high SE will get high learning results which will also affect students' higher-order thinking skills. In the learning activities in a group a student will be able to get informal information sources and support from the group. In addition, the high SC and SE are expected to maximize student learning activities which will certainly have a positive impact on learning results, including students' higher-order thinking skills (Zakiyah, Hidayati \& Setyawan, 2010).

In addition to obtaining satisfying learning result, it also requires encouragement from a positive social environment in order to create a comfortable feeling of students in completing their academic assignments. This positive social environment can be in the form of learning groups where each member must have a sense of belonging in order to achieve the same goal of obtaining good learning results, as stated by Dalton, Elias, \& Wandersman (2001: 170), where all elements in the group must have the same goals, respect each other, and support each other's efforts, and believe that everyone makes an important contribution to learning and education. Psychological community said 
feelings of security and comfort, mutual care, trust, and the presence of emotional bonds between group members is called the sense of community. If students have high SC, it will grow a feeling of safety, comfort and responsibility in their learning environment, so students avoid academic procrastination, which is the habit of delaying to complete the assignments. Students who have high SC will encourage and motivate other students in learning activities so that students will try to complete academic tasks optimally in a timely manner, so that with a high SC in students, they are expected to improve their learning results, including higher-order thinking skills of participants students (Zimmerman, 2000).

In this era mixture of face to face learning and online learning (blended learning) using the WhatsApp platform is increasingly popular due to the variations in learning modes and activities so that it is not monotonous, but also this type of learning can be done anytime and enywhere. In online learning that is done using a platform WhatsApp is expected to facilitate learning and as a complement face to face learning. This social media-assisted learning (WhatsApp) can help teachers and students to increase knowledge, improve students' high-level thinking skills in analyzing a phenomenon.

Based on several studies conducted by several researchers regarding the sense of community, namely Yilmaz (2016) and Luo, Zhang, \& Qi (2017) found a tendency that sense of community has a positive influence on student learning outcomes, but it is not yet known whether sense of community has an influence on students' high-level thinking skills. As for research on self-efficacy itself, there are already quite a lot of researchers who study in education but there is still controversy that there are differences in research results where Ahriana, Yani, \& Maruf (2016) and Jatisunda (2017) state that self-efficacy influences the results student learning while Yoannita, Budi, \& Rustana (2016) state that self-efficacy does not have an influence on learning outcomes. Based on the results of research conducted by several researchers there is still controversy, so researchers are interested in examining the effect of sense of community and self-efficacy on students' higher-order thinking skills in learning Newton's law of motion by WhatsApp-assisted.

The purpose of this study is to determine the effect of: 1). Sense of Community towards students' high-level thinking skills in learning Newton's law of motion by WhatsApp-assisted, 2). Self-efficacy of students' higher-order thinking skills in learning Newton's law of motion by WhatsApp-assisted, 3). Sense of Community and Selfefficacy towards students' high-level thinking skills in learning Newton's law of motion by WhatsApp-assisted.

\section{METHOD}

The type of research used is correlational research. This study uses two independent variables $(\mathrm{X})$ and one dependent variable $(\mathrm{Y})$. The independent variables in this study are SC and SE, while the dependent variable in this study is the ability to think at a high level. In this design there are two classes / groups selected by cluster random sampling. Where in the two classes conducted learning activities using WhatsApp-assisted learning media. The effect of SC and SE on students' high-level thinking skills can be seen from the results of filling the SC and SE scales with the assessment of student learning results. The research design used was Post-test only 
design . The research began in SMA Negeri 13 Bandar Lampung on Thursday 09 january 2019 until 23 january 2019.

\section{Research Design \& Procedures}

The research design used was Post-test only design in SMA Negeri 13 Bandar Lampung on Thursday 09 january 2019 until 23 january 2019. Data collection is carried out after the learning activities are carried out. The procedures is research observation and research implementation (learning activities and data collected)

\section{Population and Sample}

The population in this study were all students of class X MIA in SMA Negeri 13 Bandarlampung even semester of the 2019/2020 school year, amounting to 6 classes with a total of 210 students and the sample in this study was taken from $40 \%$ of the total population and obtained 2 classes namely X MIA 5 and X MIA 6. The samples in this study were determined using cluster random sampling techniques. Data collection is carried out after the learning activities are carried out.

\section{Data Collection and Instrument}

The steps taken in collecting research data, namely by providing an assessment of learning outcomes is intended to see the learning outcomes in the form of student cognitive values obtained from the provision of HOTS questions to review students' high-level thinking skills after learning. After that the SC and SE scale is distributed with various questions to find out the SC and SE of students.

The instrument used in this study is the multiple choice HOTS problem with C4C6 cognitive level that refers to Solekhah, Maharta \& Suana (2018) with a total of 15 items with alpha cronbach 0.864. A SC scale with 21 question items adapted from Roberts (1995), Rovai (2002), Rovai, Wighting \& Lucking (2004) with alpha cronbach 0.870. The SE scale with 21 question items adapted from Lin \& Tsai (2015) with alpha cronbach 0.903 .

\section{Data Analysis}

Data analysis techniques in this study used prerequisite tests such as normality test, linearity test, and multicollinearity test. To test the hypothesis using the product moment correlation test, simple linear regression and multiple linear regression.

\section{RESULT AND DISCUSSION}

Based on the results of research conducted at SMAN 13 Bandarlampung with a sample of 68 students. Frequency distribution data on students' SC variables are presented as shown in Figure 1. 


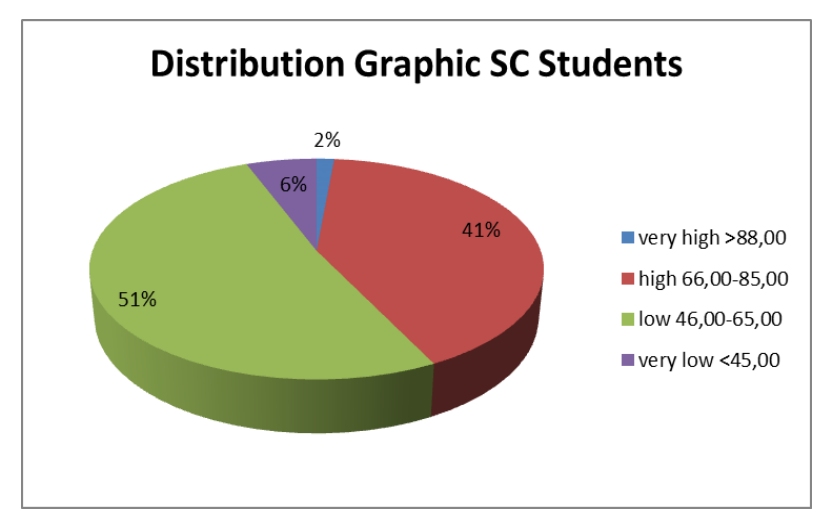

Figure 1. Distribution Graphic SC Students

Based on Figure 1 it can be seen that the highest percentage of students' SC tendencies of $51 \%$ falls into the low category with a range of grades $46-65$ of the total students overall. Based on the research data the statistical graphs depicted in the histogram of the SE distribution of students are presented as shown in Figure 2.

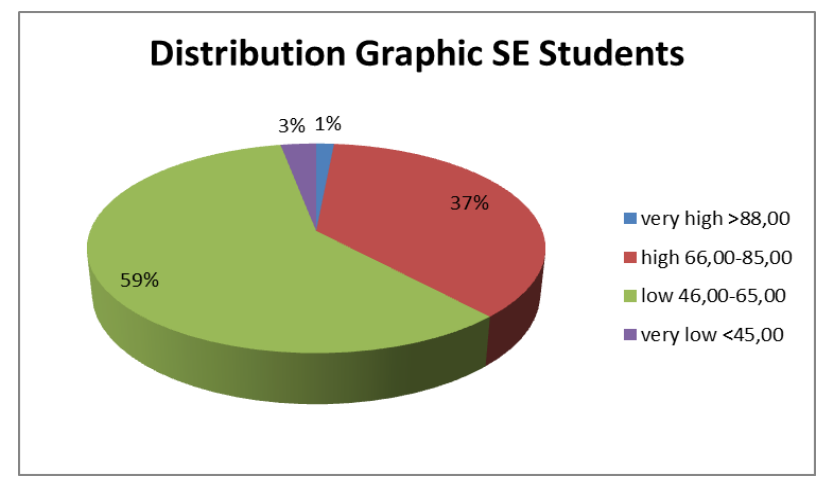

Figure 2. Distribution Graphic SE Student

Based on Figure 2, it can be seen that the percentage of SE tendencies of the highest students amounting to 59\% falls into the low category with a range of grades 4665 of the total students overall. Data from statistical chart research results is illustrated in the HOTS frequency distribution histogram of students are presented as shown in Figure 3.

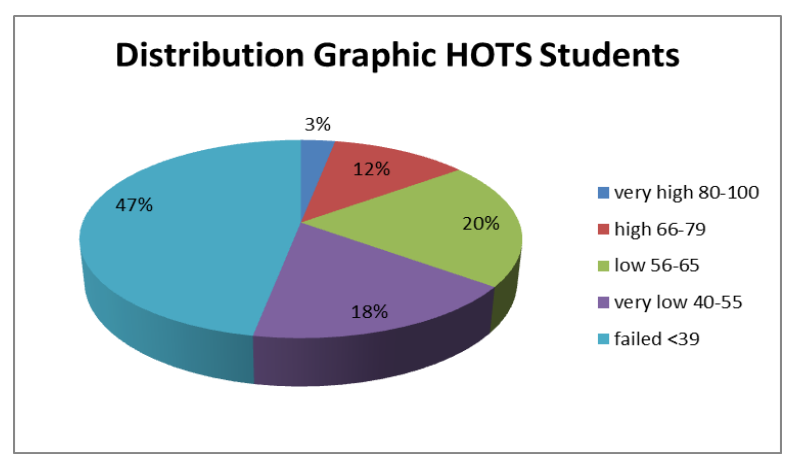

Figure 3. Distribution Grapic HOTS Student 
Based on Figure 3 it can be seen that the highest percentage of SE tendencies of students by $47 \%$ falls into the category of failure with a value $<39$ of the total students overall. From the previous elaboration, it has been explained that this study aims to investigate the effect of SC and SE on HOTS students in learning Newton's law about whatsapp-assisted motion.

Before testing the hypothesis first the normality test results of the $\mathrm{SC}, \mathrm{SE}$, and HOTS. The Asymp Table. Sig on the SC, SE, and HOTS Questions has a value of more than 0.05 , it can be said that the data is normally distributed. Based on the calculations that have been done by researchers obtained the linearity test results of the SC, SE, and HOTS. The Asymp value. Sig on the HOTS * SE and HOTS * SC data has a value of more than 0.05 , it can be said that the data has a non-linear relationship. The results of the multicollinearity test results from the SC, SE, and HOTS. The tolerance value on SC and SE data has a value of $>0.10$, it can be said that the data does not occur multicollinearity. On the VIF value on the SC and SE data has a value $<10.0$, it can be said that the data does not occur multicollinearity. Based on these results the multiple linear regression test can be continued.

Simple Linear Regression Test is used to determine the presence or absence of the influence of sample SC and sample SE on HOTS. The SC and SE Linear Regression Test on HOTS using the SPSS 21.0 program can be seen in Table 1 point number 1 and number 2. Multiple Linear Regression Test is used to determine the presence or absence of the influence of combination of SC and SE on HOTS. The combination of SC and SE Multiple Regression Test on HOTS using the SPSS 21.0 program can be seen in Table 1 point number 3.

Table 1. Simple Liniar and Multiple Linier Regression Test

\begin{tabular}{clcccc}
\hline No. & $\begin{array}{c}\text { Variable } \\
\text { Research }\end{array}$ & R & $\mathbf{R}^{2}$ & F & $\begin{array}{c}\text { Asymp. } \\
\text { Sig }\end{array}$ \\
\hline 1 & HOTS*SC & 0.095 & 0.009 & .600 & $.441^{\mathrm{b}}$ \\
2 & HOTS*SE & 0.052 & 0.003 & .178 & $.674^{\mathrm{b}}$ \\
3 & HOTS $*$ & 0.114 & 0.013 & .430 & $.653^{\mathrm{b}}$ \\
& SC, SE & & & & \\
\hline
\end{tabular}

Based on Table 1 it can be seen that the correlation value or the relationship (R) between the independent variable and the dependent variable is 0.095 which means there is a positive relationship between the SC and HOTS. Using a significance of 5\% with a value of $\mathrm{r}$ count $0.095<$. R Table 0.235 . It means that the SC has no influence on the increase in HOTS. Based on Table 4.12, the Sig. $=0.441>0.05$, it means that there is no relationship between the independent variable, SC and the dependent variable, HOTS.

Based on Table 1 it can be seen that the correlation value or the relationship (R) between the independent variable and the dependent variable is 0.095 which means there is a positive relationship between the SC and HOTS. Using a significance of 5\% with a value of $\mathrm{r}$ count $0.095<$. R Table 0.235. It means that the $\mathrm{SC}$ has no influence on the increase in HOTS. Based on Table 4.12, the Sig. $=0.441>0.05$, it means that there is no relationship between the independent variable, SC and the dependent variable, 
HOTS. The SC and SE Multiple Regression Test on HOTS using the SPSS 21.0 program can be seen in Table 5.

Based on Table 1 it can be seen that the correlation value or the relationship (R) between the independent variables together with the dependent variable is 0.114 which means there is a positive relationship between SC and SE with HOTS. Using a significance of $5 \%$ with a value of $r$ count $0.114<$. R Table 0.235 . It means that the SC and SE have no effect on the increase in HOTS. Based on Table 4.16, the Sig. $=0.653>$ 0.05 , it means that there is no relationship between the independent variable, SC, SE and the dependent variable, HOTS.

The average results of the percentage of SC and SE achieved by students after learning to use MIM is 63.68 and 63,49 included in the medium category, and the average results of HOTS achieved by students after learning activities using the blended learning model using the WhatsApp platform that is equal to 39.66 included in the low category.

The theory put forward by Zakiyah, Hidayati \& Setyawan (2010) states that the SC in students will foster a feeling of security, comfort and responsibility in their learning environment, so that students avoid academic procrastination or the habit of delaying completing assignments. Where students who have high SC will encourage and motivate other students in learning activities. Luo, Zhang \& Qi. (2017) states that in online learning, SC has a positive role in shaping students' sense of togetherness and insignificantly strengthens their sense of membership thereby increasing learning outcomes.

The results of the study show that based on hypothesis testing obtained a correlation value of 0.095 and sig value of $0.441>0.05$, so there is no influence between the SC and students 'HOTS, which means the increase in students' HOTS is not influenced by the SCs owned by these students, with the coefficient of determination R square equal to 0.009 which means that the participation of the independent variable to the dependent variable is $0.9 \%$ which can be interpreted that the SC hasn't a contribution to HOTS and the remaining $99.1 \%$ is influenced by other factors.

In line with the research results of Yilmaz (2016) revealed that the SC on students positively but not significantly (there is no relationship) affect their learning outcomes that are seen from the connection with the community, perceptions of learning in the community, and their social status in. Based on information obtained through interviews, there is no correlation between the SC and HOTS allegedly because students do not like learning that is done in groups in online classes because in completing assignments given in groups only some members do it.

According to Zimmerman (2000) SE in students can motivate learning through self-regulation in setting goals or targets, self-observation, and self-evaluation, as well as setting strategies for using learning time to achieve the goals that are targeted. The results of the study show that based on hypothesis testing a correlation value of 0.052 is obtained and a sig value of 0.674>0.05, so there is no influence between the SEs with students 'HOTS, which means the increase in students' HOTS is not influenced by the SEs owned by these students, with the coefficient of determination $\mathrm{R}$ square equal to 0.003 which means that the participation of the independent variable to the dependent variable is $0.3 \%$ so that it can be interpreted that the SC hasn't a contribution to HOTS and the rest $99.7 \%$ is influenced by other factors that's not examined by the researcher, 
such as factors personality, social-cognitive factors, environmental factors and individual condition.

Based on the results of the study found that these results are in line with research conducted by Yoanita, Budi, \& Rustana. (2016) and Yilmaz (2016) state that there is a positive but not significant relationship (there is no relationship) between SE and student learning outcomes. The absence of influence between SE and HOTS students allegedly because based on the results of interviews students stated that there is a sense of doubt in themselves when they want to express their opinions or answer questions from teachers related to learning conducted in class so that they need help from other friends.

The existence of a high SC will establish good and fun communication both in the online classroom or in the classroom. So students will have a high enthusiasm in learning because these students feel safe, comfortable and have responsibilities in their learning environment and do not feel difficulties in finding help when completing assignments so it will improve their learning outcomes. In addition, students who have a high SE will motivate themselves to follow the entire learning process well, both in elearning activities and face to face starting from curiosity, intensity in paying attention to the explanation of the lesson, reading the material to find the most effective strategy for the academic achievement, but these factors do not have an influence on HOTS students.

The results of hypothesis test on the three variables obtained a correlation value of 0.114 and sig value of $0.653>0.05$, so there is no influence between the SC, SE and HOTS of students, which means that the increase of students' HOTS is not influenced by the SC and SE of the student, with a coefficient R square determination of 0.013 which implies that the participation of the independent variable to the dependent variable is $1.3 \%$ so that it can be interpreted that SC and SE haven't an influence or contribution to HOTS and the rest of $98.7 \%$ are influenced by other factors, such as factors personality, social-cognitive factors, environmental factors and individual conditions.

Based on the results of research that has been done, it is found similarities from several other studies that examine SC and SE, which states that there is no significant effect (there is no relationship) between SC and SE on learning outcomes (Yilmaz, 2016). The absence of influence between SE and SC on HOTS students is suspected as it is known that SC and SE are the affective domain while HOTS itself is included in the cognitive domain. In the assessment of student competencies in the affective domain assessed the attitudes and interests of students in learning and the assessment process is qualitative, while the assessment of student competencies in the affective domain assessed is student learning outcomes that are more quantitative.

Some researchers such as (Krathwohl, Bloom \& Masia, 1964) make affective assessment into 5 classifications which include receiving, responding, appreciating, organizing and acting. The five affective domain classifications are carried out by the right brain which is obtained through mimicking actions, while the cognitive assessment which includes science, logic and language is carried out by the left brain which is obtained from the learning process. Basically it can be emphasized that affective assessment is indeed very qualitative in nature so it cannot be easily combined in a cognitive assessment system. It has become the allegation that HOTS students are not 
influenced by the SC and SE of students, which students who have good character do not necessarily have a high HOTS and vice versa. Students who have high HOTS may not have good character. Because both domains are run by different brains and obtained in different ways.

There is no relationship between the SC and SE of HOTS is also suspected because according to (Stanley, 2000) author of the book The Millionaire Mind. Have researched about 100 factors that determine a successful person. Research was conducted in America with a total of 1001 respondents, which 733 respondents were millionaires. The results obtained that someone who has a high IQ / superior, study in favourite school or prestigious school is not included in the 10 main factors determine one's success. It turned out that all of the things that affect a successful person are soft skills, including: honesty, hard discipline, sociable support, companion support, hard work, love of what is done, leadership, competitive personality, orderly life, and the ability to sell ideas. Based on the survey results it can be seen that the cognitive domain with the affective domain has no relationship.

Based on the results on recapitulation of questionnaire given to the students, commonly many students don't really like to learn by using WhatsApp, because in blended learning using WhatsApp, some students become not really focus, for example beside the students are getting notification from online class, there are notification from another people. Then, students' answers also can directly seen by the other students. It makes students easier to copypaste their friends or another groups' answers. On the other hand, there are some problems faced by the students in the blended learning process using WhatsApp, some of those problems are: (1) Students didn't really understand the instructions given by the teacher because it is only given in text, (2) Students lack of cooperation in their group in bringing assignment in the online class because students can not see their members' work. In other words, only students with high ability and high responsibility who will work the assignment given. All of that can strenghten the research results that SC and SE of students don't have any influence to students' HOTS ini blended learning using WhatsApp.

\section{CONCLUSION}

Based on the results of research and discussion, it can be concluded that there is no effect of SC on HOTS, SE on HOTS, and SC, SE on HOTS. Based on the conclusions, the authors advise that teachers deemed unnecessary to build SC and SE students in learning activities if they want to raise HOTS students, teachers can present material using a blended learning model with more focus and monitor all student activities and the teacher must be more focus on monitoring students who are lacking active when face to face learning or online learning discussing in groups, researchers can then consider the short duration of time, the number of samples studied and the facilities and infrastructure students that have in blended learning activities such as, do all students have WhatsApp application and have adequate internet connection and etc, so that WhatsApp can be used in the learning process. .the next researcher must also analyze the influence of other factors such as personality factors, social-cognitive factors, environmental factors and individual conditions. 


\section{REFERENCES}

Ahriana, A., Yani, A., \& Maruf, M. (2016). Studi Analisis Hubungan Antara Self Efficacy dengan Hasil Belajar Fisika Siswa Kelas XI MIA SMA Negeri 1 Takalar. Jurnal Pendidikan Fisika, 4(2), 223-238.

Budiarti, I. S., Suparmi, S., Sarwanto, S., Harjana, H., \& Viyanti, V. (2019). Stimulating Students' Higher-Order Thinking Skills on Heat and Temperature Concepts. Jurnal Pembelajaran Fisika, 7(2), 103-112.

Dalton, J. H., Elias, M. J., \& Wandersman, A. (2001). Community psychology: Linking individuals and communities. Wadsworth/Thomson Learning. Belmont: CA.

Jatisunda, M. G. (2017). Hubungan self-efficacy siswa SMP dengan kemampuan pemecahan masalah matematis. Jurnal THEOREMS (The Original Research of Mathematics), 1(2), 24-30.

Krathwohl, d.r., bloom,b.s., and masia, b. 1964. A Taksonomy Of Educational Objectives. Newyork: David Mackay.

Lin, T.-J., \& Tsai, C.-C. (2013b). An investigation of Taiwanese high school students ' science learning selfefficacy in relation to their conceptions of learning science. Research in Science and Technological Education, 31(3), 308 - 323.

Luo, N., Zhang, M., \& Qi, D. (2017). Effects of different interactions on students' sense of community in e-learning environment. Computers \& Education, 115(2), 153160.

Marliani, D., Setiawati, L. A. D., \& Walid, A. (2019). Analysis of HOTS Problem Physics of Electrical Static in MA Darussalam Bengkulu City. Jurnal Pembelajaran Fisika, 7(2), 113-118.

Marsakha, A. T., Suyatna, A., \& Herlina, K. (2020) The Effect Of Lcds-Based Interactive E-Schoolbook (Esb) Against Hots And Scientific Attitude Of Students. Jurnal Pendidikan Matematika dan IPA, 11(1), 120-129.

Roberts, W. (1995). Assessing Students' and Teachers' Sense of the School as a Caring Community. Developmental Studies Center Oakland CA, 3-26.

Rovai, A. P. (2002). Sense of community, perceived cognitive learning, and persistence in asynchronous learning networks. The Internet and Higher Education, 5(4), 319-332.

Rovai, A. P., Wighting, M. J., \& Lucking, R. (2004). The classroom and school community inventory: Development, refinement, and validation of a self-report measure for educational research. The Internet and Higher Education, 7(4), 263280.

Solekhah, F. M. A., Maharta, N., \& Suana, W. (2018). Pengembangan Instrumen Tes Kemampuan Berpikir Tingkat Tinggi Pada Materi Hukum Newton Tentang Gerak. Pascal (Journal Of Physics And Science Learning), 2(1), 17-26. 
Stanley, Thomas J. (2000). The millionaire mind. United States: Andrews Mcmell Publishing.

Yilmaz, R. (2016). Knowledge sharing behaviors in e-learning community: Exploring the role of academic self-efficacy and sense of community. Computers in Human Behavior, 63(2), 373-382.

Yoannita, B., Budi, E., \& Rustana, C. E. (2016). Pengaruh Self Efficacy Terhadap Hasil Belajar Fisika Melalui Penggunaan Model Problem Based Learning. In Prosiding Seminar Nasional Fisika (E-Journal) (pp.9-14). Unj, Yogyakarta, on 30 Oktober 2016.

Zakiyah, N., Hidayati, F. N. R., \& Setyawan, I. (2010). Hubungan antara penyesuaian diri dengan prokrastinasi akademik siswa sekolah berasrama SMP N 3 Peterongan Jombang. Jurnal Psikologi Undip, 8(2), 156-167.

Zimmerman, B. J. (2000). Self-efficacy: An essential motive to learn. Contemporary educational psychology, 25(1), 82-91. 